\title{
P215 TESTING OF GEL-TECHNOLOGY FOR FILTRATION FLOW CONTROL UNDER RESERVOIR FLOODING IN OIL FIELDS OF SOUTHERN VIETNAM SHELF
}

LYUBOV K. ALTUNINA', GERMAN N. BELIANIN², VLADIMIR A. KUVSHINOV' KAN MI LOY ${ }^{2}$, OREST F. MARTYNTSIV ${ }^{2}$, ARTUR A. FATKULLIN ${ }^{2}$ and TA DINH VINH ${ }^{2}$ 1 Russian Academy of Sciences, Institute of Petroleum Chernistry. 3 Akademichesky Avenue, 634021 Tomsk, Russia 2 JV Vietsovpetro

$\checkmark$ Drilling Mud Co.

\section{INTRODUCTION}

At present the important problem of flooding in oil fields of southern Vietnam shelf consists in filtration flow balancing of injected water. High formation temperatures limit the employment of conventional methods.

Inorganic gel-forming GALCA systems based on aluminium cloride and carbamide have been developed at the Institute of Petroleum Chemistry RAS for EOR and conformance [1-3]. Under surface conditions gel-forming systems are low viscous solutions, which under the formation conditions become gels. Gelation in situ results in modification of water injection profile, reduction of water cut and in rearrangement of filtration flows in formation. Commercial works on EOR using GALCA systems have been carried out in the West Siberia oil fields. The technology proved to be economically effective and ecologically acceptable. The period of pay back is $1-2$ years $[1-3]$.

\section{FILTRATION CHARACTERISTICS OF GEL-FORMING GALCA SYSTEMS}

The efficiency of gel-forming GALCA systems has been studied by experiment to redistribute the flow pattern and to modify water injection profile under the conditions of southern Vietnam's shelf oil fields. The experiment was carried out using a pair connected in parallel core samples of different permeability $\left(0.166-0.470 ; 1.087-13.92 \mu \mathrm{m}^{2}\right)$ recovered from Lower Miocene deposits and from the basement at the formation temperature of 130 and $140{ }^{\circ} \mathrm{C}$. It has been determined that gelation in situ caused by GALCA system at high formation temperatures modifies filtration flows of injected water because of decreased mobility in highpermeable seams. The core permeability as to water decreases from $60-150$ to $0.5-1.8 \mu \mathrm{m}^{2}$ for Lower 
Miocene and from 1680 to $97 \mu \mathrm{m}^{2}$ for the basement, respectively. If necessary reservoir permeability can be practically reduced when treated with acid solutions.

\section{FIELD TEST OF GEL-FORMING GALCA SYSTEM}

In 1996 field tests of gel technology have been successfully carried out to control filtration flows under flooding in pilot area of Lower Miocene deposit. Gel-forming GALCA system was injected into the injection well in oil field of southern Vietnam shelf at J.V. "Vietsovpetro".

$160 \mathrm{~m}^{3}$ of gel-forming GALCA system were pumped into an injection well, followed by forced injection of $200 \mathrm{~m}^{3}$ of sea water into the formation. Then the well was shut up for 9 days to generate a gel screen, following which the well was put for injection.

On treatment the injectivity remained at the same level as it was before the injection - about 600 $\mathrm{m}^{3} /$ day under the pressure of $100 \mathrm{~atm}$. After 3-month injection repeat studies of pressure and temperature profiles of injection well were carried out. The changes in pressure and temperature profiles observed in the injection well testify to redistribution of the injected water volumes through the formation depth between the working zones. Thus in a top low permeable zone of perforation one observed the injectivity increase from 5 to $15 \%$ relative to the injected water volume.

Producing wells, which are hydrodynamically connected with an injection one, responded in the following way. In two producing wells, having zero water cut, one could observe an increase in buffer pressure from 40 to 44 and from 36 to 44 atm., as well the increase in daily oil production rate from 185 to $210 \mathrm{tn}$. and from 250 to $300 \mathrm{tn}$., respectively (Figure). In the third flooded well one observed periodic water cut decrease from $20-25$ to $5-14 \%$. Further observations of well functioning are being carried out in the pilot area.

The redistribution of filtration flows and the increased conformance, caused by the injection of gel-forming GALCA system, resulted in increase of oil production and decrease of water cut in the pilot area. 


\section{CONCLUSION}

- For EOR and conformance of flooded oil fields in southern Vietnam shelf inorganic gelforming GALCA systems have been tested.

- The filtration characteristics of GALCA systems have been studied. It has been determined, that gelation in situ caused by GALCA system at high formation temperatures into a heterogeneous simulated formation model results in redistribusion of filtration flows. The mobility of liquid in a high permeable core samples sharply decreases, whereas in a lower permeable one it remains at the same level.

- In oil field of southern Vietnam shelf testing of gel-technology for filtration flow control under reservoir flooding have been carried out. in pilot area of Lower Miocene deposit. The injection of GALCA system into the injection well improves the injection profile, decreases watercut and increases oil production of the producing wells, that are hydrodynamically connected with injection one.

- Inorganic gel-forming GALCA systems are effective to control filtration flows of the formation fluids and to IOR of flooded highly temperature reservoirs in oil fields of southern Vietnam shelf.

\section{LITERATURE}

1. Altunina L.K., Bokserman A.A., Kuvshinov V.A., Polkovnikov V.V.: Inorganic Gels to Enhance Oil Recovery of High Temperature Formaitions, $7^{\text {th }}$ European IOR Symposium, $27-$ 29 October 1993. Moscow, Russia, pp. 21-30.

2. Altunina L.K., Kuvshinov V.A., Bokserman A.A., Polkovnikov V.V.: EOR by Systems with Controlled Viscosity and Alkalinity, $8^{\text {th }}$ European IOR Symposium, 15-17 May 1995. Vienna, Austria, pp. 163-168.

3. Altunina L.K., Kuvshinov V.A.: 1995. Enhance Oil Recovery by Surfactant Compositional Systems. Novosibirsk, Russia, Nauka. 198 p. (in Russian). 


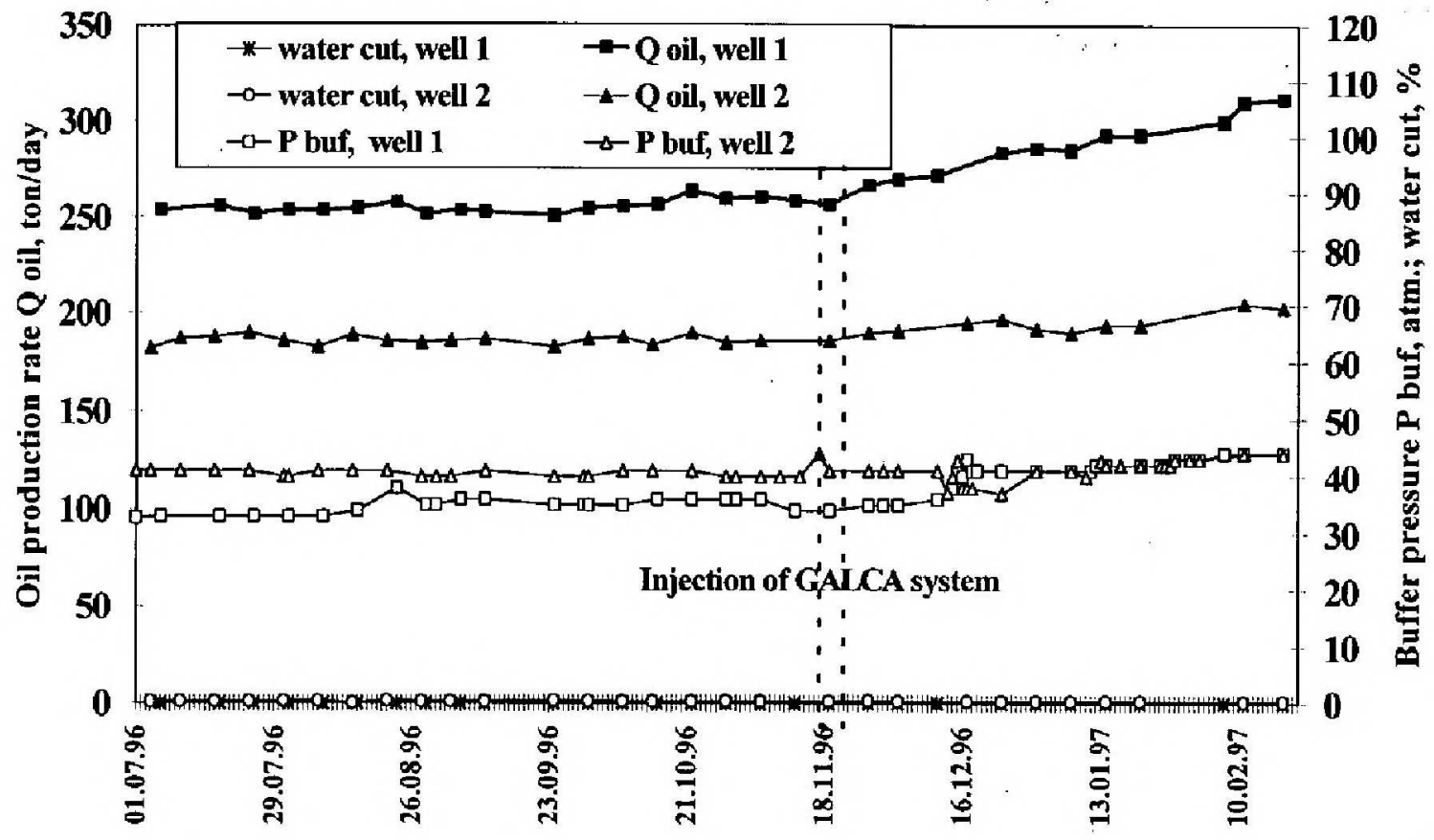

Figure. Efficiency of gel-forming GALCA system injection into the injection well at pilot area of Lower Miocene deposit in oil field of southern Vietnam shelf: increase in oil production rate and buffer pressure of produsing wells. 